\title{
THE MINISTRY OF TEACHING IN THE SUNDAY SCHOOL.
}

By Rev. Thomas D. Anderson, D.D., Central Baptist Church, Providence, R. I.

Teaching is a duty imposed on the disciples of Christ by the great commission: "Go ye and make disciples of all the nations, teaching them to observe all things whatsoever I commanded you." The teacher was one of the ministers of the early church. "He gave some to be apostles; and some prophets ; and some evangelists; and some pastors and teachers; for the perfecting of the saints, unto the building up of the body of Christ." And, surely, if we believe that our religion has a rational foundation; if we are the advocates of an intelligent faith: if, as the apostle teaches, a Christian ought to be "ready always to give answer to every man that asketh a reason concerning the hope that is in him," we must believe that in some place, at some time, in some way, definite, consecutive, systematic instruction must be imparted.

As advocates of Christianity we must teach, because we accept a book, or rather a collection of religious literature, as our rule of faith and practice. If we accepted any creed formulated by a church council, or any catechism prepared by a set of ecclesiastical teachers, as having final authority, our task of teaching would be simpler than it now is. But since we, as Protestants, demand that all creeds or confessions of faith shall be compared with the teaching of certain Holy Scriptures, and since we give to every man the right of individual judgment in passing upon the results of this comparison, we are in duty bound to give to those who are to pass sentence ample instruction in the Scriptures which must form the standard of judgment.

While the acceptance of the Bible as a standard of faith and practice lays on us the obligation to teach, that obligation is 
emphasized as we consider the character of the literature of which the Bible is composed. A large part of that literature consists of history and biography, and without a knowledge of the historic facts it is impossible to come into fullest sympathy with the religious teaching. However stimulating the words of the prophets may be, even to the uninformed reader, those words take on a new significance, gain a more fascinating charm, and, frequently, exert a more quickening influence, as they are considered in connection with the experience in which they were born. And as we turn to Him of whom the prophets did write, we find that we can be led to form a true estimate of his character only through a profound and reverent study of the experiences in which that character was revealed. Christianity is pre-eminently a historical religion, and as it cannot be understood, so, surely, it cannot be propagated without paying special attention to historical facts; he who repeats again and again the exhortation, "Come to Christ!" may well consider that the meaning of this exhortation will be proportionate to the knowledge of Christ's character possessed by the person to whom he appeals. The exhortation "Come to Christ!" is meaningless except as it has been preceded by definite instruction as to who Christ is.

Again, the literature of the Bible is not all of the same date. The time intervening between one portion of Scripture and another is often measured by centuries; and if the student of the Bible, for lack of instruction, treats the different writings as if proceeding from the same age, he is in danger of gross misinterpretation. If Abraham is to be judged by the same canons which we apply to the apostle John, and no allowance is made for those who lived in the time of the Judges as compared with those who heard the teachings of Christ, the ethical student who turns to the Scriptures for help in his perplexity will be driven by those Scriptures into a state of despair.

Once more, the statements of the Scriptures, even according to the testimony of the Scriptures themselves, are not all of equal authority. Certain biblical writers do not hesitate to impeach the authority of certain of their predecessors. Jesus, Paul, 
and the author of the epistle to the Hebrews intimate, yes, distinctly affirm, that the teaching of those olden times needs to be modified, that rites and observances once obligatory under the law are not required under the dispensation of grace, and that "the covenant made with the fathers decayeth and waxeth old and is ready to vanish away." In view of these conflicting authorities surely there is need of teaching in order to distinguish between "the things that can be shaken" and may fall, and "the things which cannot be shaken" and forever remain.

If, in general, teaching is demanded of the Christian advocate by the character of his religion, and especially by the character of the book which he accepts as a standard, it is demanded in our day that that teaching shall be systematic and exact because of the general educational advantages afforded by our public schools. Our public schools may not be beyond criticism, but in several respects they are far in advance of most of our Sunday schools. Their teaching is scientific and exact. The pupil is taught not only to observe facts, but to observe them in their relations. As his education advances, he is taught to challenge his early notions or beliefs, and not even to accept his teacher's statement, until that teacher explains his statement, and calls attention to the facts or reasons on which it is based. If, then, the religious teaching which such pupils receive consists simply of pious exhortations or dogmatic iterations of traditional beliefs, with little or no reference to the historical or rational grounds on which those beliefs are based, the pupil is likely, in intellectual reaction, either to discard religion or, at least, suspend his religious thinking, or else to regard religion as an other-worldly affair, not very closely or indissolubly connected with the affairs of this life. But when these pupils are taught that Christianity has a local habitation as well as a name, when they learn that the historical facts in which its revelations are given are connected with definite portions of the earth's surface, of which they have studied in their geography, and especially when they are brought to observe how the principles of their ancestral religion have been a potent force in the daily lives of men and of nations who have acted their part in human history, 
they will come to recognize in religion an efficient factor in human life, and with intellectual and moral natures quickened will be led to take a profounder interest in the study of its nature and its demands.

But, granting that this teaching is needed, does it follow that it must be given in the Sunday school? In reply we ask: Where else can it be given at once so generally and so well? The signs of the times seem to indicate that this teaching has been relegated to the Sunday school by common consent. Time was when religious instruction was given in the home; when around the fireside children were taught passages of Scripture, the historical facts of the Bible, or the catechism. But now the work of education, unless we except education in manners, is relegated from the home to the school. In the school, however - that is, in the public school, which the very large majority of our children attend-distinctively religious instruction is prohibited by law. It is true that in our private schools, and in our colleges which rest on private foundations, there are opportunities for religious instruction, which happily are oftentimes wisely improved. But for the general religious instruction of the people no institution has so grand an opportunity as the church with its pulpit and its Bible school. The pulpit, however, is generally regarded as a place for the application and enforcement of religious truths, rather than for the scientific exposition of the Scriptures. The people are willing, sometimes desirous, that the preacher should lead in the work of Bible study, but they prefer that he should do this work elsewhere than in the pulpit. To the Sunday school, then, the work of systematic teaching of the Bible is relegated by common consent, and hither is brought the demand for definite, consecutive, systematic instruction in that religious literature in which God's most precious revelations are recorded, and on which the church's most precious doctrines are based.

Granting that the Bible must be taught in the Sunday school, one may ask: What is the individual teacher to teach? That will depend on the experience and ability of the teacher, and even more on the experience and ability of the pupil. The 
Bible was not given to men at one time, and it is not to be taught all at once. Instruction must be graded. Selections must be made according to the appetencies of the pupil. It would not be wise to engage a young child in the study of Job or Ecclesiastes, or even to impose on him the task of fathoming the epistle to the Romans, or that to the Colossians. The child should be taught, first, the stories of the Bible. To this end the teacher may rehearse the inimitable stories preserved in the Old Testament, or may present the teaching of other portions of Scripture in the form of a story. As the pupil advances in intellectual ability and moral apprehension, he may be attracted to the characters of the Bible. He should be made familiar with Abraham and with Joseph, with Moses and with Elijah, with Joshua and with David, until he may be led to take interest in Peter, in Paul, or in John, or to find an ever-deepening satisfaction in the character of Jesus of Nazareth. Truth should be presented as God has presented it - as a living power in living men. From this study of human characters the pupil may easily be led into a study of the historical facts of the Bible. He may become interested in studying the facts of the life of Jesus, the history of Israel and Judah, considered, too, in the wider relations with Egypt, Assyria, and Babylonia, the history of the early church as recorded in the book of the Acts, until later in advanced work he may, if he chooses, seek to construct the earlier history of the Hebrews, or even the history of the Jews after the exile. After stories, characters, and an outline of picturesque facts have been considered, the profound teaching of the Bible may be made the subject of systematic study. The student may begin with that which is at once the most important and the most simply presented-the teaching of Jesus; then he may be led to consider the teachings of the prophets and lawgivers of the Old Dispensation; after these the teaching of the apostles, and later still such teachings as are found in the books of Proverbs, Job, and Ecclesiastes, or the apocalyptic utterances in the book of Daniel or the so-called book of the Revelation.

In some such way the subject-matter may be graded. But 
in all grades there is need of careful teaching. Men have often commented on the simplicity of the teaching of Jesus, but does not the history of interpretation prove by abundant evidence how a literal application of very simple words often leads men into error, and how conduct which is ethically censurable is sometimes justified by an appeal to the plain teaching of Christ? Is there not need of wise instruction in setting forth the true import of the teaching expressed in the command, "Resist not him that is evil," or in the injunction, "If thy right eye cause thee to stumble, pluck it out"? Will the young mind unguided always rightly interpret the parable of the Unjust Steward, or even that of the Laborers in the Vineyard? Can we believe that without a study of the method of Jesus' teaching we can exactly determine what that teaching is? And if we are obliged to take account of method in order rightly to interpret the teachings of Jesus, which are presented in so remarkably simple a form, it surely need not surprise us if we shall be obliged to allow for the influence of current conceptions when expounding the more obscure teachings of prophets, psalmists, or apocalyptists, or to take into account Jewish modes of thought, and even rabbinical methods of instruction, in the interpretation of some of the more perplexing statements of the apostle Paul.

But if this careful work of interpretation is to be done, we must do something more than simply reiterate the statements of Scripture. In order rightly to interpret the Bible it is not sufficient simply to be familiar with the words of Scripture. One must know something of the circumstances amid which those words were uttered, and of the motives with which they were expressed. Indeed, one cannot fully understand what the Bible says, until he has a reasonably correct conception of what the Bible is; and for instruction as to the nature and composition of the Bible the demand is becoming increasingly strong.

The careful, conscientious student is not long in discovering that he cannot always take individual passages at their face value; he cannot accept every statement of the Bible as the 
literal description of an actual historical fact, or as the final statement of an ultimate religious truth. One statement negatives another statement; a universal affirmation at one point is balanced by a partial denial at another. The Bible certainly cannot be regarded simply as a moral or religious code in which the rules of life are expressed in exact and unalterable form; therefore the question presses: What is the Bible? And to this question some answer ought to be given in Sunday-school instruction. In some schools, in some classes of some schools, or at least somewhere in our Sunday-school curriculum, instruction ought to be given as to the nature and composition of the Bible.

What is the Bible? How did it come into being? How are its different parts related to each other? What is its authority? What authority does it claim for itself? Are all its statements of equal authority, and all its teachings final? What is its literary character? Are we to treat it as if it were all plain prose, or are we to recognize in it the play of the poet's fancy? Is every declaration a literal statement of historical fact, or is truth sometimes put forth in the form of fiction? Should it be regarded as a scientific text-book addressed particularly to the intellect, or as an impassioned but yet reasonable appeal to the heart, out of which are the issues of life? Is it such a book that we may use it as a grab-bag, assured that the verse we draw out is an infallible deliverance coming immediately from the Spirit of God; or is it a composite literature, recording the experiences of many men, of many ages, in whose multiform experiences we find revelations at once of God and of man, and from which we are to make our inferences as to the nature of God, the destiny of man, and the conditions on which God and man may come into intimate and eternal union? Now, these are perfectly legitimate questions. They are asked by many in our day, and they ought to receive a reasonable answer; and can we say that our Sunday schools are meeting the demands made upon them if they fail to provide, somewhere in their system of instruction, an opportunity for the thoughtful study of the problems suggested by these questions, ofttimes most honestly asked and sometimes most earnestly pressed? 
If some such teaching as has been outlined is demanded at the present day, how can these demands be supplied? The demands certainly are exacting; yet they are not all made of the individual teacher, but only of our Sunday-school system. It is not demanded that everyone who meets a class should be an accomplished teacher, but it is most urgently demanded that we should have accomplished teaching in our Sunday-school curriculum, and we now venture to present one or two suggestions as to the way in which this better type of teaching may be secured.

If there is one teacher available who is capable of conducting a normal class in which young men and young women may be prepared to become intelligent teachers of the Bible, let him (or her) start a normal class. Into this class gather those who have an intellectual desire to understand the Bible, and a religious desire, or at least willingness, to teach their fellows. After these have had a general training in Bible study, let one prepare himself (or herself) to teach the life of our Lord, another to teach the lives of the prophets or great men of the Old Testament, and yet another to teach the history of the apostolic church. As each takes a limited department of study, he is likely to become increasingly efficient in that department, and scholars who really desire to learn something may pass from one teacher to another, enjoying competent instruction in a course of study extending over three or more years. Perhaps later some member of the normal class may be ready to conduct a study in the teaching of Christ, or the teaching of the prophets, or the teaching of the apostles.

If in some schools it is impossible to find a teacher competent to conduct a normal class, it may still be possible to find two or three teachers who will give their attention to different departments of Bible study, and thus prepare themselves to give increasingly efficient instruction in these departments. If such may be found, place them as teachers in the departments they have chosen, and keep them there until it shall be known that, at least in those departments, careful, intelligent, systematic instruction is offered in the school. 
The time has come when our force of instructors ought to be organized. We need to divide the work and apportion it to different teachers. In our general educational curriculum we do not ask one instructor to teach an entire course in mathematics from arithmetic to conic sections. Why should we, in our Sunday-school curriculum, ask one instructor to teach the whole Bible from the story of Joseph to the Acts of the Apostles and the Apocalypse of John; from the parables of the Master to the epistle to the Romans and the book of Job? Already our best Sunday-school workers have recognized the need of establishing grades in our course of instruction. Is it not time to take the advanced step and make this graded instruction still more efficient by assigning different teachers to the different grades? If specialization has contributed to more efficient instruction in schools devoted to the study of natural science and general literature, why should we not expect it to contribute to more efficient instruction in schools devoted to the interpretation of the Bible?

It is not necessary that all schools should be graded at once, nor that every school which may well have two or three graded classes should at once carry the graded system throughout the entire school. For this general result, however desirable it may be, ideally, probably very few schools are now prepared. But the establishment of a few classes in the graded system, with the more competent instruction which may be reasonably expected from specialized teaching, will materially help the work by holding many whose tenure on the Sunday school is now slight, and in attracting to our schools earnest young people, who are hungering for more intelligent and more satisfactory instruction in the Bible.

It is a happy augury for the success of the graded system that now, when the demand for graded teaching is so strong, the helps which may be used in preparation for such teaching are so numerous and commendable. The need of adopting uniform lessons, in order to secure the best helps, is not so great as it was a few years ago. The helps for consecutive or systematic study of different parts of the Bible are now considerable. We 
have the series prepared by the Bible Study Union and the constructive studies of the American Institute of Sacred Literature, and there are constantly issuing from the press works admirably adapted to help the teacher of ordinary intelligence to perform efficient work in the systematic teaching of the Bible.

It is true that the style of teaching here emphasized, and for which there is an increasing demand in our day, cannot be given without paying the price. The Sunday school cannot perform the work which is demanded of it by an enlightened Christian church without labor on the part of many. But vicarious suffering, which is the condition of our advancing civilization, is also the central principle of the religion which we profess. If, then, we are under Christian obligation to interpret God's word to our own and the coming generation, we may not excuse ourselves on so thoroughly un-Christian a plea as unwillingness to labor. The obligation we may not deny; for believing, as we do, in the vital importance of the teaching of the Bible to the perpetuation of Christianity, we are bound to be teachers. If those who come after us are to be swayed by the principles inculcated in the Bible, they certainly must be taught what those principles are; and if they are to exercise an intelligent faith rather than grovel in ignorant superstition, our teaching must be intelligent, scientific, and exact, as well as reverent, earnest, and persistent.

The Bible has always needed an interpreter; it needs an interpreter today. The obligation resting upon the Christian church, to be discharged very largely through the Sunday school, is to interpret to those now living the words of the everliving God. If the Bible is to continue to be a living book, its truths must be comprehended, exemplified, interpreted anew by each successive generation of men. There is a perennial suggestiveness in the conversation between Philip, the evangelist, and the eunuch, who was found reading Isaiah the prophet: "Understandest thou what thou readest?" "How can I, except someone shall guide me?" 